deformation?". J Am Soc Hypertens, 10 (9), pp. 694-701.

7. Tientcheu D, Avers C, Das SR, McGuire DK, de Lemos JA, Khera A, Kaplan N, Victor R, Vongpatanasin W (2015) "Target Organ
Complications and Cardiovascular Events Associated With Masked Hypertension and WhiteCoat Hypertension: Analysis From the Dallas Heart Study". Journal of the American College of Cardiology, 66 (20), pp. 2159-2169.

\title{
ĐÁNH GIÁ CHẤT LƯỢNG CUỘC SỐNG Ở PHU NỮ MÃN KINH VÀ YẾU TỐ LIÊN QUAN TẠI THÀNH PHỐ CẦN THO' NĂM 2020
}

\section{TÓM TẮT}

Đặt vấn đề: Mãn kinh là thời kỳ của sự rối loạn hoạt động nội tiết trong cơ thể gây ra nhiều biến đổi về thể chất và tâm thần, ảnh hưởng đến chất lượng cuôc sống của người phu nữ. Muc tiêu: (1) Đánh giá chất lượng cuộc sống ở phụ nữ mãn kinh tại thành phố Cần Thơ năm 2020. (2) Tìm hiểu một sổ yếu tố liên quan đến chất lượng cuộc sống ở phụ nữ mãn kinh tại thành phố Cần Thơ. Đối tượng và phương pháp nghiên cứu: Nghiên cứu mô tả cắt ngang 259 phu nữ mãn kinh (từ 45-60 tuổi) có hô khẩu thường trú tại thành phố Cần Thơ từ tháng 5 đến tháng 9 năm 2020. Đánh giá chất lượng cuộc sống phư nữ mãn kinh bằng bộ công cự The Women's Health Questionaire (WHQ). Kết quả: Trung bình điểm chất lượng cuộc sống của phụ nữ mãn kinh 45-60 tuổi là $75,8 \pm 9,0$ điểm. Phụ nữ mãn kinh có chất lượng cuộc sống tốt chiếm $60,6 \%$. Phân tích đa biến ghi nhận 3 yếu tố thật sự liên quan đến chất lượng cuộc sống của phụ nữ mãn kinh (45-60 tuổi), trong đó, chất lượng cuộc sống của phụ nữ mãn kinh tốt hơn ở nhóm cư trú sống ở nông thôn, không mắc bênh mãn tính và không tiếp cận thông tin chăm sóc sức khỏe mãn kinh với $p<0,05$. Kết luân: chất lượng cuôc sống ở phụ nữ mãn kinh từ $45-60$ tuổi chưa cao, hơn $1 / 3$ phụ nữ mãn kinh có chất lượng cuộc sống chưa tốt. Cần tăng cường truyên thông can thiệp nâng cao chất lượng cuộc sống đối với phu nữ mãn kinh.

Tư khóa: mãn kinh, chất lượng cuộc sống, yếu tố liên quan

\section{SUMMARY}

\section{THE QUALITY OF LIFE AND ASSOCIATED FACTORS AMONG MENOPAUSAL WOMEN IN CAN THO CITY, 2020}

Background: During menopausal period, there are a lot of fluctuation in hormone levels making various mental and physical disorders, affecting to quality of life (QOL) for women. Objectives: (1) To assess the quality of life among menopausal women in Can Tho city, 2020. (2) To define some factors

${ }^{1}$ Trường Đại học Y dược Cần Thơ

${ }^{2}$ Bênh viên Phu sản thành phố Cần Thơ

Chịu trách nhiệm chính: Nguyễn Minh Phương

Email: nmphuong@ctump.edu.vn

Ngày nhận bài: 22.12 .2020

Ngày phản biên khoa hoc: 25.01.2021

Ngày duyệt bài: 8.2 .2021

\section{Nguyễn Minh Phương ${ }^{1}$, Lê Thị Kim Định ${ }^{2}$}

associated to quality of life among menopausal women in Can Tho city. Subjects and research methods: A cross-sectional study was conducted on 259 menopausal women (from 45-60 years) who have been permanent residence in Can Tho city from May to September 2020. The Women's Health Questionaire (WHQ) was used to assess the quality of life among menopausal women. Results: The mean QOL score among menopausal women from $45-60$ years was $75,8 \pm 9,0$. The QOL with good level among menopausal women was accounted for $60,6 \%$. There were three associated factors to QOL among menopausal women, in which, QOL was better for women in rural area, without chronic desiases and not approaching menopausal health care information ( $p$ $<0,05)$. Conclusions: The quality of life among menopausal women is not high and more than one third of them poor QOL. Communication interventions of QOL should be strengthened for menopausal women.

Keywords: menopausal women, quality of life, associated factors

\section{I. ĐĂTT VẤN ĐỀ}

Mãn kinh là giai đoạn cuối cùng của kinh kỳ trong cuộc đời người phụ nữ, là một hiện tượng sinh lý tự nhiên, thường xảy ra ở phụ nữ lứa tuổi 45-55; tuổi mãn kinh trung bình phụ nữ Việt Nam là $52 \pm 3,27$ [2]. Do điều kiện sống và việc chăm sóc sức khỏe được cải thiện nên tuổi thọ trung bình của người dần đã tăng. Tuổi thọ càng cao thời kỳ mãn kinh càng kéo dài. Như vậy người phụ nữ phải trải qua một phần ba cuộc đời trong tình trạng thiếu hụt estrogen, do đó, không thể tránh khỏi những rối loạn tiền mãn kinh, mãn kinh. Đây là thời kỳ biểu hiện ngừng kinh nguyệt vĩnh viễn một cách tự nhiên do buồng trứng không còn hoạt động, nồng độ các hormon giảm thấp. Sự biển đổi này kéo theo những thay đổi về tâm sinh lý và sức khỏe người phụ nữ [1], như rối loạn về vận mạch, bệnh lý niệu sinh dục và những bệnh lý lấu dài khác (loãng xương, các bệnh về tim mạch). Các rối loạn có thể xảy ra một cách êm đềm hay phối hợp nhiều rối loạn như bốc hỏa, vã mồ hôi đêm, rổi loạn giấc ngủ, khô âm đạo, giảm ham muốn tình dục, ,...[9]. Chính các rối loạn này ảnh hưởng trực tiếp đến chất lượng cuộc sống (CLCS) cũng 
như hiệu quả lao động cũng như hạnh phúc gia đình của phụ nữ giai đoạn trước, trong và sau mãn kinh.

Để đánh giá đầy đủ CLCS của phu nữ mãn kinh, cần một bộ công cụ phải có đủ yếu tố hiện đại, tính ứng dụng, giá trị và khác với dân số chung. Hiện nay, có 5 bộ câu hỏi đáp ứng được các tiêu chuẩn trên là The Green Climacteric Scale (21 câu; 3 lĩnh vực vận mạch, tâm thần và thực thể), The Menopausal Symptom List (56 câu; 4 lĩnh vực tâm thần, vận mạch, thực thể, sức khỏe), The Menopause Rating Scale (11 câu; 3 lĩnh vực tâm thân, thực thể và triệu chứng cơ thể), The Utian Menopause Quality of Life Score (23 câu; 4 lĩnh vực nghề nghiệp, sức khỏe, tâm thần và tình dục); trong đó, The Women's Health Questionaire (WHQ) là một bộ công cụ sử dụng rộng rãi trong nhiêu nghiên cứu nhằm đánh giá CLCS của phụ nữ trước và sau mãn kinh từ 45-65 tuổi. So với các bộ công cụ khác, WHQ có nhiều ưu điểm trong đánh giá CLCS phụ nữ mãn kinh như số câu hỏi phù hợp (23 câu), thời gian khảo sát ngắn (5-7 phút); đánh giá đầy đủ các khía cạnh (6 lĩnh vực: lo âu trầm cảm, sức khỏe, triệu chứng cơ thể, vận mạch, trí nhớ/tập trung, rối loạn giấc ngủ); đã được thử nghiệm chuẩn hóa với độ tin cậy cao (hệ số tin cậy các lính vực từ $0,74-0,98)$; sử dụng đa quốc gia, đã dịch sang nhiều ngôn ngữ (27 ngôn ngữ, trong đó có Tiếng Việt) [5], [8]. Một số nghiên cứu đánh giá CLCS của nhóm phụ nữ mãn kinh 40-60 tuổi như Phạm Thị Vân Như [7] (năm 2013) tại Lâm Đồng có điểm trung bình CLCS phụ nữ mãn kinh là 62,9; Trần Thị Thanh Nhàn [6], Hoàng Thị Liên [4] nghiên cứu tại Huế năm 2013 ghi nhận phụ nữ mãn kinh có CLCS tốt chiếm tỷ lệ lần lượt là $11,5 \%$ và $14 \%$; tỷ lệ này ở nghiên cứu của Nguyến Thị Hòa (năm 2018) [3] tại Hải Phòng chiếm 41,9\%. Kết quả các nghiên cứu cho thây CLCS của phụ nữ mãn kinh (40-60 tuổi) không cao, dao động từ 11-40\%. Tại Đồng bằng Sông cửu long, đặc biệt tại thành phố Cần Thơ ít nghiên cứu về CLCS của phụ nữ mãn kinh.

\section{Mục tiêu nghiên cứu:}

- Đánh giá chất lượng cuộc sống ở phụ nữ mãn kinh tại thành phố Cần Thơ năm 2020.

- Tìm hiểu một số yếu tố liên quan đến chất lượng cuộc sống ở phụ nữ mãn kinh tại thành phố Cần Tho.

\section{II. ĐỐI TƯƠNNG VÀ PHƯƠNG PHÁP NGHIÊN CỨU}

2.1 Đối tượng nghiên cứu. Phu nữ mãn kinh từ 45-60 tuổi có hộ khẩu thường trú tại thành phố
Cần Thơ từ tháng 5 đến tháng 9 năm 2020.

Tiêu chuẩn chọn vào: Phụ nữ mãn kinh từ 45-60 tuổi (không có kinh ít nhất trong 12 tháng) có hộ khẩu thường trú tại thành phố Cần Thơ ( $\geq 6$ tháng) trong thời gian nghiên cứu và đồng ý tham gia nghiên cứu.

Tiêu chuẩn loại trừ: Những phụ nữ không còn minh mẫn để trả lời chính xác các câu hỏi được phỏng vấn hoặc hạn chế khả năng giao tiếp; bệnh lý nội, ngoại khoa tiến triển nặng; ung thư'; bệnh lý về tâm thần, thiểu năng trí tuệ hoặc han chế nhân thức, năng lực, hành vi; phụ nữ dùng nội tiết tố thay thế; tiền sử cắt tử cung và phần phụ.

\subsection{Phương pháp nghiên cứu}

Thiết kế nghiên cứu: Nghiên cứu mô tả cắt ngang.

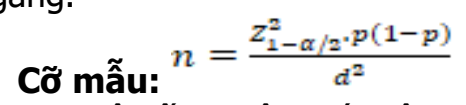

- Z: hệ số tin cậy; với độ tin cậy $95 \%$ thì $Z_{1}$ $\mathrm{a} / 2=1,96$

- p: tỷ lệ chất lượng cuộc sống đạt tốt ở phụ nữ mãn kinh. Chọn $p=0,419$ [3]

- d: sai số cho phép. Chọn $d=0,06$.

Thay vào công thức ta đước $n=259$.

Phương pháp chọn mấu: Chọn mẫu theo phương pháp phân tầng

Bước 1: Bốc thăm ngẫu nhiên chọn 01 quận và 01 huyện nghiên cứu.

Bước 2: Bốc thăm ngẫu nhiên chọn 01 phường/xã ở mỗi quận/huyện đã chọn ở bước 1 .

Bước 3: Chọn ngẫu nhiên 1 hộ gia đình trong danh sách. Các hộ tiếp theo được chọn liền kề bên phải của hộ gia đình đã chọn.

Bước 4: Chọn đối tượng phù hợp tiêu chuẩn chọn mẫu. Trường hợp có nhiều đối tượng thỏa tiêu chuẩn thì bốc thăm ngẫu nhiên chọn 1 đối tượng/hộ gia đình. Trường hợp, hộ gia đình không có đối tượng thỏa tiêu chuẩn chọn mẫu thì chọn hộ gia đình tiếp theo đến khi đủ 259 đối tượng.

Nội dung nghiên cứu: Chất lượng cuộc sống phụ nữ mãn kinh: thang điểm trả lời của bộ câu hỏi WHQ dựa vào thang đo Likert (1- 4 điểm) đánh giá CLCS của phụ nữ 45-65 tuổi trên 6 lĩnh vực với 23 câu gồm lo âu/ trầm cảm (7 câu); đánh giá sức khỏe (4 câu); triệu chứng cơ thể (5 câu); trí nhớ/ tập trung (3 câu); triệu chứng vân mach (2 câu); vấn đề giấc ngủ (2 câu). Điểm WHQ từ 23-92 điểm, dựa trên phân vị thứ 50 và 75 , phân CLCS thành 3 mức độ là thấp (WHQ < 58 điểm), trung bình (58-74) và cao (WHQ > 74 điểm). Chia thành 2 nhóm là CLCS tốt (WHQ > 74 điểm) và CLCS chưa tốt (WHQ $\leq 74$ điểm). Một số yếu tố liên quan đến 
CLCS: Đắc điểm dân số học, tình trạng dinh dưỡng, tiền sử bệnh, thói quen sinh hoạt.

Xử lý và phân tích số liệu: phân mên SPSS 18.0. Mô tả số liệu bằng tỷ lệ (\%), trung bình, độ lệch chuẩn. Xử lý yếu tố liên quan đến CLCS bằng phương pháp hồi qui logistic đa biến, sự khác biệt có ý nghĩa thống kê với $p<0,05$.

\section{KẾT QUẢ NGHIÊN CỨU}

\section{1. Đặc điểm chung}

Bảng 1. Đặc điểm về tuôî, dân tộc, kinh tế, dịa dur

\begin{tabular}{|c|c|c|c|}
\hline \multicolumn{2}{|c|}{ Đặc điểm chung } & $\begin{array}{c}\text { Tân số } \\
\text { (n=259) }\end{array}$ & $\begin{array}{c}\text { Tỷ } \\
\text { lệ\%\% }\end{array}$ \\
\hline \multirow{2}{*}{$\begin{array}{c}\text { Nhóm } \\
\text { tuối }\end{array}$} & $45-54$ & 73 & 28,2 \\
\cline { 2 - 4 } & $55-60$ & 186 & 71,8 \\
\cline { 2 - 4 } & Trung bình & $56,3 \pm 4,6$ \\
\hline \multirow{2}{*}{$\begin{array}{c}\text { Dân } \\
\text { tộc }\end{array}$} & Kinh & 255 & 98,5 \\
\cline { 2 - 4 } & Khác & 4 & 1,5 \\
\hline \multirow{2}{*}{$\begin{array}{c}\text { Kinh } \\
\text { tế }\end{array}$} & Nghèo/cận nghèo & 14 & 5,4 \\
\cline { 2 - 4 } & Không nghèo & 245 & 94,6 \\
\hline \multirow{2}{*}{$\begin{array}{c}\text { Địa } \\
\text { dư }\end{array}$} & Thành thị & 144 & 55,6 \\
\cline { 2 - 4 } & Nông thôn & 115 & 44,4 \\
\hline
\end{tabular}

Tuối trung bình là 56,3 \pm 4,6; tỷ lệ nhóm 4554 và $55-60$ là $28,2 \%$ và $71,8 \% ; 98,5 \%$ dân tộc Kinh, tỷ lệ hộ nghèo/cận nghèo chiếm 5,4\%; $55,6 \%$ sống ở thành thị.

Bảng 2. Đăc điểm về nghề nghiệp, học vấn, hôn nhân, sốcon

\begin{tabular}{|c|c|c|c|}
\hline \multicolumn{2}{|c|}{ Đặc điểm chung } & $\begin{array}{c}\text { Tân số } \\
\text { (n=259) }\end{array}$ & $\begin{array}{c}\text { Tỷ lệ } \\
\text { \%o }\end{array}$ \\
\hline \multirow{4}{*}{$\begin{array}{c}\text { Nghề } \\
\text { nghiệp }\end{array}$} & Nông dân & 7 & 2,7 \\
\cline { 2 - 4 } & Công nhân & 8 & 3,1 \\
\cline { 2 - 4 } & $\begin{array}{c}\text { Côngôn bán } \\
\text { chức (CCúc, viên }\end{array}$ & 65 & 25,1 \\
\cline { 2 - 4 } & Nghî hưu & 11 & 4,2 \\
\cline { 2 - 4 } & Nội trợ & 146 & 8,5 \\
\hline Học vấn & < Trung học phố & 182 & 70,3 \\
\hline
\end{tabular}

\begin{tabular}{|c|c|c|c|}
\hline & thông (THPT) & & \\
\hline & $\geq$ Trung học phố thông & 77 & 29,7 \\
\hline \multirow{2}{*}{$\begin{array}{l}\text { Hôn } \\
\text { nhân }\end{array}$} & $\begin{array}{l}\text { Sống cùng chồng } \\
\text { và con cái }\end{array}$ & 202 & 78,0 \\
\hline & Khác & 57 & 22,0 \\
\hline \multirow{3}{*}{ Số con } & Không có con & 31 & 12,0 \\
\hline & $1-2$ con & 159 & 61,4 \\
\hline & $>2$ con & 69 & 26,6 \\
\hline
\end{tabular}

Nghề nghiệp chủ yếu là buôn bán và nội trợ, chiếm $25,1 \%$ và $56,4 \%$; thấp nhất là nông dân với 2,7\%; 29,7\% trình độ từ THPT trở lên; $12,4 \%$ còn độc thân; $12 \%$ phu nữ không có con cái.

3.2. Đánh giá chất lượng cuộc sống phụ nữ mãn kinh từ 45-60 tuổi

Bảng 3. Mức độ chất lượng cuộc sông phy nữ mãn kinh từ 45-60 tuổi

\begin{tabular}{|c|c|c|c|}
\hline \multicolumn{2}{|c|}{ Mức độ CLCS } & $\begin{array}{c}\text { Tân số } \\
(\mathbf{n = 2 5 9 )}\end{array}$ & $\begin{array}{c}\text { Tỷ } \\
\text { lệ\% }\end{array}$ \\
\hline \multirow{2}{*}{$\begin{array}{c}\text { Mức độ } \\
\text { CLCS }\end{array}$} & Thấp & 11 & 4,2 \\
\cline { 2 - 4 } & Trung bình & 91 & 35,1 \\
\cline { 2 - 4 } & Cao & 157 & 60,6 \\
\hline \multicolumn{2}{|c|}{ Trung bình (điếm) } & \multicolumn{2}{|c|}{$75,8 \pm 9,0$} \\
\hline
\end{tabular}

Điếm trung bình chất lượng cuộc sống phụ nữ mãn kinh là 75,8 \pm 9,0; mức độ CLCS thấp, trung bình và cao lân lượt là $4,2 \%$; $35,1 \%$ và $60,6 \%$.

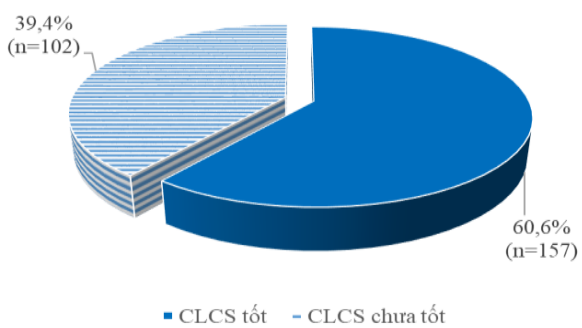

\section{Biểu đồ 1. Phân loại chât lượng cuộc sông} phụ nữ mãn kinh từ 45-60 tuổi

Chất lượng cuộc sống phụ nữ mãn kinh mức tốt chiếm 60,6\%; chất lượng không tốt chiếm 39,4\%.

3.3. Một số yếu tố liên quan chất lượng cuộc sống phụ nữ mãn kinh từ 45-60 tuổi

Bảng 4. Phân tích đa biến liên quan giữa phù nữ mãn kinh có CLCS tốt và một số yếu tố

\begin{tabular}{|c|c|c|c|c|}
\hline \multirow{2}{*}{ Yếu tố } & \multicolumn{2}{|c|}{ Phân tích đơn biến } & \multicolumn{2}{c|}{ Phân tích đa biến } \\
\cline { 2 - 5 } & OR (KTC 95\%) & $\mathrm{p}$ & OR (KTC 95\%) & $\mathrm{p}$ \\
\hline Tuối (45-54/55-60) & $1,475(0,835-2,604)$ & 0,179 & $1,347(0,692-2,623)$ & 0,381 \\
\hline Địa dư (Nông thôn/thành thị) & $2,286(1,359-3,844)$ & $\mathbf{0 , 0 0 2}$ & $2,278(1,262-4,11)$ & $\mathbf{0 , 0 0 6}$ \\
\hline Tôn giáo (Có/không) & $0,590(0,356-0,979)$ & $\mathbf{0 , 0 4}$ & $0,74(0,413-1,324)$ & 0,310 \\
\hline $\begin{array}{c}\text { Kinh tế (Nghèo, cận } \\
\text { nghèo/không nghè̀) }\end{array}$ & $1,180(0,384-3,626)$ & 0,773 & $1,486(0,428-5,166)$ & 0,533 \\
\hline Nghề nghiệp (Nội trợ/khác) & $1,440(0,867-2,393)$ & 0,158 & $0,854(0,473-1,54)$ & 0,600 \\
\hline Học vấn ( $\geq$ THPT/<THPT) & $1,025(0,594-1,770)$ & 0,928 & $1,384(0,717-2,671)$ & 0,333 \\
\hline Con cái (Không con/có con) & $1,208(0,553-2,640)$ & 0,636 & $1,951(0,595-6,391)$ & 0,270 \\
\hline $\begin{array}{c}\text { Hôn nhân (Sống cùng chồng vàn } \\
\text { con/khác) }\end{array}$ & $1,053(0,578-1,919)$ & 0,865 & $1,05(0,422-2,613)$ & 0,916 \\
\hline
\end{tabular}




\begin{tabular}{|c|c|c|c|c|}
\hline TCBP (Không/có) & $1,921(1,152-3,201)$ & $\mathbf{0 , 0 1 2}$ & $1,563(0,871-2,804)$ & 0,135 \\
\hline Béo bụng (Không/có) & $1,771(1,070-2,930)$ & $\mathbf{0 , 0 2 6}$ & $1,16(0,624-2,158)$ & 0,639 \\
\hline Bệnh mãn tính (Không/có) & $2,513(1,505-4,196)$ & $\mathbf{< 0 , 0 0 1}$ & $1,843(1,021-3,326)$ & $\mathbf{0 , 0 4 3}$ \\
\hline Thể dục (Có/không) & $1,902(1,138-3,180)$ & $\mathbf{0 , 0 1 4}$ & $1,25(0,668-2,34)$ & 0,486 \\
\hline $\begin{array}{c}\text { Tham gia sinh hoạt tập thế } \\
\text { (Có/không) }\end{array}$ & $1,322(0,682-2,566)$ & 0,408 & $1,196(0,547-2,615)$ & 0,654 \\
\hline Uống sữa (Có/không) & $0,783(0,450-1,363)$ & 0,386 & $1,135(0,582-2,213)$ & 0,709 \\
\hline $\begin{array}{c}\text { Tiếp cận thông tin chăm sóc } \\
\text { sức khỏe mãn kinh(Không/có) }\end{array}$ & $3,126(1,853-5,274)$ & $\mathbf{< 0 , 0 0 1}$ & $2,698(1,497-4,864)$ & $\mathbf{0 , 0 0 1}$ \\
\hline
\end{tabular}

Phân tích đơn biến cho thấy có 7 yếu tố liên quan đến CLCS phụ nữ mãn kinh là địa dư, tôn giáo, TCBP, béo bụng, bệnh mãn tính, thể dục và tiếp cận thông tin chăm sóc sức khỏe mãn kinh với $p<0,05$. Phân tích đa biến, ghi nhận 3 yểu tố thật sự liên quan đến CLCS của phụ nữ mãn kinh (4560 tuổi) là địa dư, bệnh mãn tính và tiếp cận thông tin chăm sóc sức khỏe mãn kinh với $p<0,05$.

\section{BÀN LUẬN}

4.1. Đặc điểm chung. Tuổi trung bình ở nghiên cứu là $56,3 \pm 4,6$. The Women's Health Questionaire là một bộ công cụ đo lường chất lượng cuộc sống cho phụ nữ trong độ tuổi 45-65 và đã được sử dụng rộng rãi trong nhiêu nghiên cứu cắt ngang và nghiên cứu tiền cứu nhằm đánh giá chất lượng cuộc sống của phụ nữ quanh tuổi mãn kinh/mãn kinh. Tham khảo các y văn về đánh giá chất lượng cuộc sống bằng công cụ Women' Health Questionair ở phụ nữ 45-65 tuổi, bộ công cụ này phân tích các nhóm từ 45$54,55-60$ và $60-65$ [8], do đó, để phù hợp với bộ công cụ, nghiên cứu phân thành 2 nhóm tuổi là 45-54, 55-60. Kết quả ghi nhận tỷ lệ nhóm 4554 và $55-60$ lần lượt là $28,2 \%$ và $71,8 \%$.

Trong 259 phụ nữ mãn kinh tham gia nghiên cứu; có hơn $1 / 2$ đối tượng sống ở thành thị; chiếm $55,6 \%$; do đó, tỷ lệ hộ nghèo/cận nghèo cũng chiếm tỷ lệ thấp là $5,4 \%$. Do nghiên cứu thực hiện tại trển các hộ gia đình có hộ khẩu thường trú tại Cần Thơ nển đối tượng chủ yếu là dân tộc Kinh, chiếm 98,5\% cũng như nghiên cứu trên phụ nữ, nên đa số nghề nghiệp là nội trợ chiếm $56,4 \%$; buôn bán cũng là nghề mưu sinh chủ yếu của phụ nữ $(25,1 \%)$; tỷ lệ nông dân chiếm tỷ lệ thấp nhất $(2,7 \%)$; trình độ học vấn từ THPT trở lên chiếm gần $1 / 3$ các đối tượng với $29,7 \%$. Khảo sát tình trạng hôn nhân của đối tượng, kết quả cho thây, số phụ nữ đang sống cùng vợ chồng và con cái chiếm $78 \%$; còn lại là sống độc thân/góa/ly thân chiếm 22,0\%; đa số thực hiện tốt kế hoạch hóa gia đình có $1-2$ con chiếm $61,4 \%$; > 2 con chiếm $26,6 \%$; tỷ lệ không sinh con chiếm khá cao (12,0\%).

4.2. Đánh giá chất lượng cuộc sống phụ nữ mãn kinh từ 45-60 tuô̂i. Trung bình điểm chất lượng cuộc sông của phụ nữ mãn kinh 4560 tuổi là 75,8 $\pm 9,0$ điểm. Phạm Thị Vân Như [7] đánh giá chất lượng cuộc sống phụ nữ sau mãn kinh có điểm trung bình là $62,9 \pm 13,1$; giá trị này ở nghiên cứu của Trần Thị Thanh Nhàn là $53,92 \pm 11,98$ [6]; nghiên cứu của Hoàng Thị Liên [4] là 55,39 $\pm 13,6$; Nguyễn Thị Hòa [3] ghi nhận điểm trung bình CLCS là $65,4 \pm 7,8$. Nhìn chung, điểm trung bình CLCS ở nghiên cứu của chúng tôi cao hơn. Do thang đo đánh giá chất lượng cuộc sống của nghiên cứu chúng tôi là The Women's Health Questionaire với 23 câu hỏi, trên 6 lĩnh vực. Trong khi đó, nghiên cứu của Phạm Thị Vân Như sử dụng thang đo The Utian Menopause Quality of Life Score (23 câu; 4 lĩnh vực); Hoàng Thị Liên, Trần Thị Thanh Nhàn và Nguyển Thị Hòa đánh giá trên thang đo WHO QoL - BREF (26 câu, 4 lĩnh vực). Như vậy, nhóm đối tượng 45-60 tuổi thật sự có nhiều thang đo đánh giá chất lượng cuộ̣c sống, tuy nhiên, thực tế, thang đo của chúng tôi có nhiêu ưu điểm hởn và phù hợp hơn nếu đánh giá trên đối tượng là phụ nữ mãn kinh từ 45-60 tuổi. Mặc khác, các nghiên cứu này đã thực hiện vài năm trước đây (từ năm 2013-2018), yếu tố thời gian cũng là một vấn đề quan trọng trong cải thiện chất lượng cuộc sống vì dịch vụ y tế cũng như các vấn đề liền quan đến chăm sóc sức khỏe sinh sản ở nước ta ngày càng cải thiện.

Đánh giá mức độ chất lượng cuộc sống của phụ nữ mãn kinh từ 45-60 tuổi cho thấy mức độ CLCS thấp, trung bình và cao lần lượt là $4,2 \%$; $35,1 \%$ và $60,6 \%$. Phân loại CLCS thành 2 nhóm là tốt và chưa tốt, trong đó, CLCS tốt chiếm $60,6 \%$. Như vậy, nghiên cứu của chúng tôi cho thấy hơn $1 / 3$ phụ nữ mãn kinh 45-60 tuổi có chất lượng cuộc sống chưa tốt $(39,4 \%)$. Điều này có ý nghĩa quan trọng đối với việc chăm sóc sức khỏe sinh sản, vì nghiên cứu cho thấy hiện tại trong cộng đồng phụ nữ mãn kinh 45-60 tuổi, cụ thể là tại thành phố Cần Thơ, cứ 3 người thuộc nhóm đối tượng này thì có ít nhất 1 người có chất lượng cuộc sống chưa tốt. Tuy nhiên, 
thực trạng này vẫn có thể được xem là khả quan hớn so với các địa phương khác. Tỷ lệ chất lượng cuộc sống tốt ở nghiên cứu của chúng tôi cao hơn nhiêu so với các nghiên cứu của tác giả khác. Hoàng Thị Liên (năm 2013) [4] và Trần Thị Thanh Nhàn [6] (năm 2016) nghiên cứu tại Huế, chất lượng cuộc sống tốt ở phụ nữ mãn kinh 50-60 tuổi tương ứng $14 \%$ và $11,5 \%$. Nguyễn Thi Hòa (năm 2018)[3], chất lượng cuộc sống tốt của phụ nữ mãn kinh tại Hải Phòng chiếm $41,9 \%$. Như đã lý giải ở trên, thang đo CLCS có sự khác biệt; đặc điểm của đối tượng nghiên cứu khác nhau từng vùng địa phương cũng như tác động của yếu tố thời gian nên tình trạng CLCS ở nghiên cứu không giống nhau.

4.3. Mốt số yếu tố liên quan đến chất lương cuộc sống phụ nữ mãn kinh từ 45-60 tuổi. Phân tích đơn biến cho thấy có 7 yếu tố liên quan đến CLCS phụ nữ mãn kinh là địa dư, tôn giáo, TCBP, béo bụng, bệnh mãn tính, thể dục và tiếp cận thông tin chăm sóc sức khỏe mãn kinh với $p<0,05$. Trong đó, nhóm phụ nữ mãn kinh có CLCS tốt hơn ở nhóm sống ở vùng nông thôn; không tôn giáo; không TCBP; không béo bụng; không bênh mãn tính; có tập thể dục; không tiếp cận với thông tin chăm sóc sức khỏe mãn kinh. Áp dụng phương pháp phân tích hồi quy đa biến để loại trừ các biến số không thật sự ảnh hưởng đến CLCS của phư nữ mãn kinh, kết quả ghi nhận còn $3 / 7$ yếu tố thật sự liên quan là nơi cư trú, tình trạng bệnh mãn tính, tình hình tiếp cận thông tin chăm sóc sức khỏe mãn kinh. Trong đó, nhóm phụ nữ sống ở nông thôn có CLCS tốt hơn nhóm sống ở thành thị 2,278 (KTC $95 \% 1,262-4,11$ ) lần với $p=0,006$. Thực tế, nhóm phụ nữ sống ở nông thôn có môi trường yên tĩnh và ít ôn ào, áp lực hơn so với phụ nữ thành thị. Phụ nữ mắc bệnh mãn tính có nguy cơ CLCS kém hơn nhóm không mắc bệnh 1,843 (KTC 95\% 1,021-3,326) lần với $p=0,043$. Khi phụ nữ không mắc bệnh thì trạng thái sức khỏe cũng như tinh thần tốt hơn so với nhóm mắc bệnh. Khi mắc các bệnh mãn tính, người bệnh phải điều trị và cần sự can thiệp y tế hàng ngày và kéo dài suốt đời. Thời gian bệnh càng kéo dài, uống thuốc điều trị lâu ngày cũng gây các tác dụng phụ không mong muốn, kèm thêm các biến chứng do bệnh mang lại, ảnh hưởng đến thể trạng của người bệnh, tăng sự mệt mỏi, lo âu, thậm chí trầm cảm. Chính điều này gây giảm sút chất lượng cuộc sống của người mắc bệnh. Kết quả phù hợp với một số nghiên cứu khác. Trần Thi Thanh Nhàn ghi nhân yếu tố liên quan đến chất lượng cuộc sống phụ nữ mãn kinh là bệnh mãn tính, trong đó, mắc bệnh mãn tính có CLCS kém hơn 2,22 lần so với không mắc bệnh (KTC 95\% 1,4-3,54) với $p=0,001$ [6]. Tình trạng bệnh tật ảnh hưởng xấu đến CLCS của phụ nữ mãn kinh cũng được ghi nhận ở nhiêuu nghiên cứu trước đây[9].

Nhóm không tiếp cận thông tin chăm sóc sức khỏe mãn kinh có tỷ lệ CLCS tốt cao hơn nhóm còn lại 2,698 (KTC 95\% 1,497-4,864) với $\mathrm{p}=0,001$. Qua quá trình khảo sát ghi nhận, lý do đối tượng tiếp cận thông tin chăm sóc sức khỏe mãn kinh vì chịu ảnh hưởng nhiều bởi các triệu chứng của mãn kinh hoặc các vấn đề sức khỏe khác. Do đó, trong quá trình tìm đến các dịch vụ y tế, được các cán bộ y tế tư vấn rõ hơn về nguyên nhân cũng như các thông tin liên quan chăm sóc sức khỏe thời kỳ mãn kinh. Điều này cho thấy nhiều phụ nữ mãn kinh 45-60 tuổi đối mă̆t với vấn đề rối loạn do mãn kinh và nhu cầu tiểp cận thông tin về chăm sóc sức khỏe mãn kinh khá cao. Để CLCS của phụ nữ càng được nâng cao hơn, ngành y tế cần xem xét ưu tiển giải pháp truyền thông chăm sóc sức khỏe về mãn kinh cho phụ nữ trước, trong và sau mãn kinh (40-65 tuổi), để ho có kiến thức, kỹ năng phòng các rối loạn thời kỳ trước mãn kinh và biết cách xử trí giảm các triệu chứng do rối loạn sau mãn kinh.

\section{KẾT LUÂ̂N}

Trung bình điểm chất lượng cuộc sống của phụ nữ mãn kinh 45-60 tuổi là 75,8 \pm 9,0 điểm; tỷ lệ chất lượng cuộc sống phụ nữ mãn kinh mức tốt chiếm $60,6 \%$. Phân tích hồi quy đa biến ghi nhận 3 yếu tố thật sự liên quan đến CLCS của phụ nữ mãn kinh, trong đó, nhóm phụ nữ sống ở nông thôn có CLCS tốt hơn nhóm sống ở thành thị 2,278 (KTC 95\% 1,262-4,11) lần với $\mathrm{p}=$ 0,006; phụ nữ mắc bệnh mãn tính có nguy cơ CLCS kém hơn nhóm không mắc bệnh 1,843 (KTC 95\% 1,021-3,326) lần với $p=0,043$; nhóm không tiếp cận thông tin chăm sóc sức khỏe mãn kinh có tỷ lệ CLCS tốt cao hơn nhóm còn lại 2,698 (KTC 95\% 1,497-4,864) với $p=0,001$.

\section{TÀl LIÊU THAM KHẢO}

1. Bộ môn Phụ sản Trường Đai học $Y$ Dược Huế (2007), Sản phụ khoa, Nhà xuất bản Y học Hà Nội.

2. Phạm Minh Đức và cộng sự (2004), Nghiên cứu thực trang sức khỏe sinh sản của phụ nữ Việt Nam mãn kinh và đề xuất các giải pháp can thiệp nhằm nâng cao chất lượng sông của phụ nữ lứa tuổi này, Báo cáo tổng kết đề tài độc lập cấp Nhà Nước, Bố Khoa học-Công nghệ, Hà Nội, tr.53.

3. Nguyến Thị Hòa (2018), "Đánh giá chất lượng cuộc sống ở phụ nữ mãn kinh tại huyện Kiến Thụy, 
Hải Phòng", Tạp chí nghiên cứu khoa học, tập 2 (1), tr. 62-66

4. Hoàng Thi Liên, Lương Thanh Bảo Yến, Võ Văn Thắng (2014), "Chất lượng cuộc sống và các yếu tố liên quan ở phụ nữ mãn kinh tại thành phố Huế", Tạp chí y tế công cộng, số 6, tr.33-37.

5. Trịnh Hoài Ngọc (2013), Hiệu quả của đi bộ và tư vấn về rối loạn quanh mãn kinh tại bệnh viện Từ Dũ, Luận văn tốt nghiệp bác sỹ nội trú, Đại học Y dước Hồ Chí Minh.

6. Trân Thị Thanh Nhàn (2016), "Nghiên cứu chất lương cuộc sống và yếu tố liên quan ở phụ nữ mãn kinh thành phố Huế", Tạp chí y tế công cộng, Tập 6 (42), tr. 42-47.
7. Pham Thị Vân Như (2016), "Đánh giá chất lượng cuộc sống của phụ nữ sau mãn kinh và các yếu tố liên quan tai huyên $\mathrm{Di}$ Linh, tỉnh Lâm Đồng", Tạp chí y học thành phố Hồ Chí Minh, Tập 20 (1), tr. 241-246.

8. Hunter MS (2000), "The Women's Health Questionnaire (WHQ): the development, standardization and application of a measure of mid-aged women's emotional and physical health". Quality of Life Res, 9, 733-738.

9. Sudhaa Shama, Neha Mahajan (2015), "Menopausal symptoms and its effect on quality of life in urban versus rural women: A cross-sectional study", Journal Midlife Health, Vol 6 (1); pp. 16-20.

\title{
ĐĂC ĐIỂM LÂM SÀNG VÀ PHÂN LOAI BÊNNH TĂNG SẢN THƯợNG THÂ̂N BẨM SINH THỂ THIỂU 21-HYDROXYLASE
}

\author{
Vũ Chí Dũng*,**, Trần Huy Thịnh*, Trần Vân Khánh*
}

\section{TÓM TẮT}

Tăng sản thượng thận bẩm sinh thể thiếu 21hydroxylase là bệnh gẩy nên do đột biến gen CYP21A2 làm mất hoăc thiếu hụt enzym 21hydroxylase, một enzym then chốt tham gia vào quá trình tổng hợp cortisol, dẫn đến hậu quả là không tổng hợp hoặc giảm tổng hợp cortisol, tăng tổng hợp testosterone đưa đến hình ảnh lâm sàng suy thượng thận cấp, nam hóa đơn thuần ở trẻ gái và dậy thì sớm ở trẻ trai. Bệnh có biểu hiện lâm sàng đa dạng và được phân loại thành 3 thể bệnh chính: mất muối, nam hóa đơn thuân, không cổ điển. Việc phân loại thế bênh và theo dõi đăc điểm lâm sàng ở bênh nhân tăng sản thượng thận bẩm sinh có ý nghĩa quan trọng trong chẩn đớn và điều trị bênh. Nghiên cứu thực hiên với mục tiêu: Xác định tỉ lệ các thể bệnh và đặc điểm lâm sàng của bênh nhân tăng sản thượng thẩn bẩm sinh do thiếu hụt enzym 21-hydroxylase. 209 bênh nhân được phân tích và đánh giá đăc điểm lâm sàng tại Bệnh viện Nhi Trung Ương. Kết quả cho thấy, đã phát hiện được $77 \%$ bệnh nhân thể mất muối, $21 \%$ thể nam hóa đơn thuần chiếm và $2 \%$ mắc thể không cổ điển. Bênh nhân thể mất muối và thể không cổ điển được chẩn đoán sớm hơn (32 ngày và 18,5 ngày) so với bệnh nhân thể nam hóa đơn thuần (1590 ngày) $(p<0.001)$. Thể bệnh mất muối có tỉ lệ nam/nữ gần tương đương nhau (nam $46,6 \%$ và nữ $54,4 \%$ ). Thể nam hóa đớn thuần có tỉ lể bênh nhân nữ cao hơn $(81,8 \%$ nữ và $18,2 \%$ nam). Mơ hồ giới tính ở bênh nhân nữ ở cả ba thể mất muối, nam hóa đơn thuân và không cổ điển là tương đương nhau (lần lượt $96 \%, 97 \%$, và $100 \%$ ). Cơn suy thượng thận cấp chỉ

\footnotetext{
*Trường Đại học Y Hà Nội

**Bệnh viện Nhi Trung ương

Chiu trách nhiệm chính: Trần Vân Khánh

Email: tranvankhanh@hmu.edu.vn

Ngày nhận bài: 14.12.2020

Ngày phản biện khoa học: 25.01.2021

Ngày duyệt bài: 8.2.2021
}

xuất hiện ở bệnh nhân thể mất muối với tỉ lệ ở nam là $91,8 \%$, ở nứ là $78,6 \%$.

Tứ khóa: Tăng sản thượng thận bẩm sinh, 21 Hydroxylase, Đặc điểm lâm sàng, thế bệnh

\section{SUMMARY \\ CLINICAL CHARACTERISTICS AND CLASSIFICATION OF 21-HYDROXYLASE DEFICIENT - CONGENITAL ADRENAL HYPERPLASIA}

21-hydroxylase deficient - congenital adrenal hyperplasiais a disease caused by a mutation in the CYP21A2 gene, resulting loss of function of the 21hydroxylase enzyme, a key enzyme involved in the synthesis of cortisol, resulting in reduced cortisol synthesis, increased testosterone synthesis which lead to the clinical manifestations of acute adrenal failure, virilizing in girls and early puberty in boys. The disease vary in term of clinical manifestations and is classified into three major disease categories: salt wasting, simple virilizing, and non-classical. Classification of disease and clinical characteristics in patients with congenital adrenal hyperplasia is important in the diagnosis and treatment of the disease. Objective: To determine the incidence and clinical characteristics of patients with congenital hyperplasia due to 21hydroxylase deficiency. 209 patients admited to the National Children Hospital were analyzed and evaluated clinically. Results showed that $77 \%$ of patients were classified as salt wasting, $21 \%$ as simple virilizing and $2 \%$ as non-classical. Patients in the salt wasting and non-classical group were diagnosed earlier (32 days and 18.5 days) than those in the simple virilizing group (1590 days) $(p<0.001)$. The proportion of males / females were nearly equal in salt wasting group (46.6\% males and $54.4 \%$ females). Simple virilizing group has a higher proportion of female patients ( $81.8 \%$ female and $18.2 \%$ male). The incident of gender ambiguity in female patients in all three categories of salt loss, male and female, were similar (96\%, 97\%, and 100\%, respectively). Acute 